\title{
Article \\ An Analysis of the Financial Liquidity Management Strategy in Construction Companies Operating in the Podkarpackie Province
}

\author{
Grzegorz Zimon ${ }^{1, *}\left(\mathbb{D}\right.$, Joanna Nakonieczny ${ }^{1}(\mathbb{D})$, Katarzyna Chudy-Laskowska ${ }^{2}{ }^{(D)}$ \\ Magdalena Wójcik-Jurkiewicz ${ }^{3}(\mathbb{D})$ and Konrad Kochański ${ }^{4}(\mathbb{D})$ \\ 1 Department of Finance, Banking and Accountancy, The Faculty of Management, Rzeszow University of \\ Technology, 35-959 Rzeszow, Poland; j.nakonieczny@prz.edu.pl \\ 2 Department of Quantitative Methods, The Faculty of Management, Rzeszow University of Technology, \\ 35-959 Rzeszow, Poland; kacha877@prz.edu.pl \\ 3 Department of Accounting, Institute of Management, College of Management Sciences and Quality, \\ Cracow University of Economics, 31-510 Krakow, Poland; magdalena.wojcik-jurkiewicz@uek.krakow.pl \\ 4 Department of Accounting, Faculty of Economics, Finance and Management, University of Szczecin, \\ 70-453 Szczecin, Poland; konrad.kochanski@usz.edu.pl \\ * Correspondence: gzimon@prz.edu.pl
}

check for

updates

Citation: Zimon, Grzegorz, Joanna

Nakonieczny, Katarzyna

Chudy-Laskowska, Magdalena

Wójcik-Jurkiewicz, and Konrad

Kochański. 2022. An Analysis of the

Financial Liquidity Management

Strategy in Construction Companies

Operating in the Podkarpackie

Province. Risks 10: 5. https://

doi.org/10.3390/risks10010005

Academic Editor: Wing-Keung Wong

Received: 21 November 2021

Accepted: 20 December 2021

Published: 29 December 2021

Publisher's Note: MDPI stays neutral with regard to jurisdictional claims in published maps and institutional affiliations.

Copyright: (c) 2021 by the authors Licensee MDPI, Basel, Switzerland. This article is an open access article distributed under the terms and conditions of the Creative Commons Attribution (CC BY) license (https:// creativecommons.org/licenses/by/ $4.0 /)$.

\begin{abstract}
The activity of each construction company in conditions of high competitiveness is exposed to a number of risks that make it difficult to maintain high financial liquidity. In order to provide the continuity of ongoing economic processes and to be able to develop, entities are forced to build optimal financial management strategies for them. Enterprises can choose between a conservative, moderate and aggressive strategy, which is largely determined by the way they manage their current assets and short-term liabilities. In the case of construction companies, it is also not without significance that they are particularly sensitive to fluctuations in the economic situation and changes in the macroeconomic environment, which imply the availability of funds. The purpose of this paper is to analyze the financial liquidity management strategy of construction sector Polish enterprises from the Podkarpackie Province in 2017-2019 and the impact of this strategy on the profitability of the surveyed entities. In order to achieve the goal, the issues related to the classification of financial liquidity and individual liquidity management strategies are discussed. The issues and the goal set determined the choice of research methods. Literature studies, the Mann-Whitney U test, cluster analysis and Ward's method were used. The research was carried out on a group of the 10 largest construction companies from the Podkarpackie Province. The selection of entities for the research was deliberately based on enterprises that submit their financial statements to the National Court Register. The conducted research showed that small and large enterprises applied different liquidity management policies even though they operate in the same industry and region. The small entities preferred a conservative strategy, while large entities preferred a moderate strategy. The existence of an inverse relationship between the phenomenon of financial liquidity and profitability of economic entities was also confirmed.
\end{abstract}

Keywords: financial liquidity; risks; SMEs; profitability; construction sector

\section{Introduction}

The construction sector is one of the most important sectors of the national economy. The activity of construction companies is closely correlated with the macroeconomic situation in a country, and at the same time has a significant impact on the functioning of units related to, among others, the production of building materials, transport or interior design. Therefore, the financial situation of construction enterprises affects the condition of other entities. Financial liquidity is the basic determinant of the efficient functioning of each economic entity, and at the same time determines its competitive position in the 
market. The sector's sensitivity to economic fluctuations and the experience of the past years related to the bankruptcy of many construction companies indicate the need for continuous monitoring of financial liquidity.

A lack of financial liquidity is the "first step" towards the bankruptcy of a company. The current pandemic context clearly shows that disrupted supply chains and delays in payments cause many companies to fail. Large enterprises generally have a positive working capital buffer that can protect them from financial difficulties in the short term. In the case of SMEs, a lot depends on the liquidity management strategy chosen by the company's management. If they decide on a risky strategy characterized by high profits and low financial liquidity, their enterprises may find it difficult to stay in the market. Currently, a better choice is to try to build high profits, but with this profitability based on financial security characterized by at least an average level of financial liquidity.

The years 2017-2019 in the Polish economy were a period of boom in the construction market, during which companies sought to rebuild their financial liquidity. The reason for this situation was the excellent situation in the housing construction market, the office and warehouse market, an increase in investments by entities in buildings and structures, and the boom in local government investment-related to the financial situation of construction companies and the unstable condition of the industry at the top of the boom (BIG 2019). Until the end of 2019, most construction companies focused on improving their results by selecting profitable ventures from private and public investors. An improvement in their financial condition became noticeable, as the entities generated a net financial result almost twice as high in 2019 (PLN 1455 million) compared to 2017 (PLN 808 million) (Wskaźniki-wskaznikibranzowe.pl 2021; BIG 2019). Attention was also drawn to a prudent pricing policy and a safer bid valuation. On the other hand, the biggest barriers to development were strong competition in the industry, a lack of professionals, high labor costs and subcontracting services, high prices of building materials, excessive tax burdens and unstable legal and tax regulations. These factors, despite the good economic situation, exerted a negative impact on the financial liquidity of construction companies, regardless of the size of their operations. However, the current financial liquidity ratios in 2017-2019 remained stable and oscillated around 1.65-1.69, while the average quick financial liquidity ratios were 1.12 for 2017 and 2018 and 1.13 for 2019, respectively (BGK 2019).

The necessity to manage financial liquidity and build an appropriate management strategy in this area results from the need to eliminate or reduce the risk of loss of financial liquidity, which, as shown by the previous experience of enterprises, is particularly probable in the period of fierce competition for orders. The concept of financial liquidity has gained particular importance in the construction sector, which drew many conclusions resulting from the market collapse in 2012-2013, related, inter alia, to the implementation of unprofitable infrastructural contacts related to, inter alia, EURO 2012. It is also an important issue from the point of view of the growing popularity of the concept of the sustainable development of construction companies. In the construction sector, this concept manifests itself in the use of a number of pro-ecological solutions, such as the use of ecological materials, the reduction of energy demand or proper arrangement of green areas. Possessing an appropriate liquidity management strategy that guarantees financial stability is a prerequisite for the sustainable development of a company and thus may contribute to an increase in the standard of living of the present and future generations.

This paper focuses on the financial liquidity of construction companies and the examination of the liquidity management strategy in 2017-2019, i.e., in the period before the SARS-CoV-2 pandemic, as well as determining the impact of this strategy on the profitability of entities. This issue is still current and it is particularly important due to the key influence of the construction industry on the national economy. It is also of interest to numerous groups of institutions from the business environment: creditors, insurers and investors. The timeliness of tasks and, consequently, access to funds depends on the organizational efficiency of construction companies. The practical significance of the conducted research is related to the determination of trends in the environment of construction 
companies from the analyzed area regarding the preferred strategies of financial liquidity management and the ability to cope with the same in a highly risky and competitive market.

\section{Literature Review}

In the research on the subject, the concept of financial liquidity is defined in various ways to distinguish individual aspects of financial liquidity (Mosiejko et al. 2019). Regardless of the term used, its behavior is the basic condition for the functioning and credibility of each enterprise in the eyes of contractors. Higgins (2009) in his study carries out a classification of the definition of financial liquidity, distinguishing three basic groups: financial liquidity in terms of assets, capital and assets and cash flow.

The first group lists definitions indicating a close relationship between financial liquidity and the entity's assets, which are characterized by a different degree of liquidity, thus determining the structure of the company's balance sheet (Waśniewski and Skoczylas 2004; Wedzki 2003). Financial liquidity in this context is defined as an ability to convert assets into cash in the shortest possible time and without losing their value, with the lowest transaction costs associated with this exchange. Financial liquidity is identified as being the most important determinants affecting the predictor of financial bankruptcy (Chen et al. 2021; Chłodnicka and Zimon 2020). Financial liquidity and profitability are strongly related to working capital. Therefore, the level of the net working capital should be carefully monitored as it has a large influence on the choice of financial liquidity management strategy (Sharma and Kumar 2011; Akgün and Ayyüce 2021).

The second definition is more popular and refers to the company's ability to pay its liabilities on time. This approach, referred to as liquidity in terms of assets and capital, is found, among others, in the studies of Wędzi (2003) and Sierpińska and Jachna (1999). The most frequently quoted definitions of liquidity include financial liquidity, meaning the company's ability to pay its short-term liabilities on time (Salehi et al. 2019; Zimon and Tarigh 2021; Higgins 2009). An example may be the definition of Kusak (2006), which determines financial liquidity in the short-term horizon and relates to the possibility of meeting the liabilities due within up to one year. In this case, an assessment is made as to whether the current assets owned by the entity are large and liquid enough to allow a timely repayment of liabilities. Maintaining financial liquidity is facilitated by maintaining in an appropriate amount both highly liquid assets and liabilities, the long maturity of which allows for their timely repayment (Wawryszcuk-Misztal 2007; Kusak 2006; Higgins 2009; Garcia-Appendini and Montoriol-Garriga 2013).

One of the static liquidity classifications refers to the company's assets, and it distinguishes financial liquidity in relation to its assets. The space defined in this way is described in the research on the subject of financial liquidity in terms of assets (Gajdka and Walińska 2000; Goldmann 2014).

In the research on the subject, one can find many studies whose authors claim that high liquidity negatively affects the level of profitability (Chowdhury and Zaman 2018; Ding et al. 2013; Enqvist et al. 2014; Bei and Wijewardana 2012; Vahid et al. 2012; Andrew and Osuji 2013; Mamatzakis and Bermpei 2014; Puławska 2021; Clampit et al. 2021; Mun and Jang 2015; Hendrick 1997; Zimon 2020). Deloof (2003), using cash the conversion cycle for 1009 Belgian firms, also finds negative relationships between gross profit, net working capital components and financial liquidity. Therefore, company managers should prevent situations in which companies possess excess liquidity because it costs money. More and more companies notice that increasing the level of profits, productivity and efficiency is possible thanks to corporate social responsibility and intellectual capital (Popescu and Popescu 2019). In the case of large enterprises, this will certainly be a factor positively influencing the financial security of enterprises.

Currently, however, during the COVID-19 pandemic, companies are departing from this type of assumption. In many industries, one can observe the situation of mass purchases and filling warehouses in order not to stop production or sales continuity (Zimon et al. 2021). The shortages of certain raw materials, products and semi-finished products appearing in all 
industries causes an additional increase in prices, which justifies the policy of accumulating excessive stocks in warehouses.

The selection of an appropriate liquidity management strategy is therefore highly dependent on the industry, company size and macroeconomic situation. In this article, we analyze liquidity management strategies in the construction industry, which is developing strongly in Poland.

\section{Methodology}

The research was carried out in a group of the 10 largest construction companies operating in the Podkarpackie Province. These companies support practically the entire construction market in the Podkarpacie region. They were divided into two groups: large enterprises (eight enterprises) and small enterprises (two enterprises). The analyzed enterprises were divided into large enterprises and SMEs based on the Accounting Act and EU regulations. In the fundamental sense, SMEs are currently defined in the Act of 6 March 2018. Entrepreneurs' law (i.e., Journal of Laws 2019, item 1292), in art. 7 of the Act. The basic criteria that are taken into account when determining the company's status are:

- number of employees-employees,

- yearly turnover,

- total annual balance sheet.

The financial analysis was carried out on the basis of the financial statements for the period 2017-2019 submitted by enterprises to the National Court Register.

In this paper the following hypotheses are presented:

Hypothesis 1 (H1). It is assumed that large enterprises obtain higher results of profitability ratios than small enterprises. Large enterprises with numerous branches in many cities operate similarly to purchasing groups and achieve economies of scale, which allows them to obtain a high margin on sales. The effect of scale obtained has a large impact on high profitability (Hendrick 1997; Schneller 2000; Eldomiaty et al. 2018; Samiloglu and Dermigunes 2008; Zimon and Zimon 2020).

Hypothesis 2 (H2). Small construction companies face a liquidity risk because they employ aggressive liquidity management strategies. Furthermore, small firms have a high amount of current assets with a low degree of liquidity (Peel et al. 2000; Garcia-Teruel and Martmez-Solano 2007; Chiou et al. 2006) which may have a negative impact on the financial security of enterprises. A weak negotiating position prevents the use of safe strategies (Zimon et al. 2021).

Hypothesis 3 (H3). It is assumed that large enterprises obtain high financial liquidity. The conducted research allows for the conclusion that the economies of scale have a positive effect on the financial liquidity management policy. (Nollet and Beaulieu 2005; Nollet et al. 2017; Burns 2002; Zimon and Zimon 2020; Cowan et al. 2016; Doucette 1997).

The Mann-Whitney U test was used to check whether there were differences in the indicators adopted for the study.

The Mann-Whitney test is the non-parametric equivalent of the Student's t-test for independent samples. It is used when there are two groups to compare for some quantitative variable, exactly as in the aforementioned Student's t-test. The Mann-Whitney test is a non-parametric test, which means that it can also be used when the data distribution does not meet the criterion of fitting to the normal distribution and when the data distribution is significantly asymmetric to the mean; it can also be used when the quantitative variable is ordinal. This test does not require the assumption that the compared groups are equal to be met.

The analysis was carried out in 2017-2019, i.e., the period before the COVID-19 pandemic.

In further research, the methods of multidimensional comparative analysis, i.e. cluster analysis, were used. The term was introduced by Tryon (1939) and further elaborated on 
by Cattell (1944). This method enables a clear and precise division of the units under the survey (in this case construction companies) characterized by many features (eventually, eight indicators were adopted) into clusters (groups) of objects similar to each other in terms of the features selected for the study. Thanks to cluster analysis, it is possible to check to what extent construction companies are similar to each other in terms of financial liquidity.

Basic descriptive statistics were used to characterize the traits. An agglomeration grouping method, the Ward method, was used for the analysis. The method uses the analysis of variance approach in its procedures (Grabiński 1992). It aims to minimize the sum of squared deviations of any two clusters that may be formed at any stage of the research. The sequence of proceedings in the Ward's method is similar to that used in the other agglomeration methods. There are significant differences in the parameters used in the formula. The scheme of the procedure is as follows: it starts with the determination of a taxonomic distance matrix with dimensions $n \times n$, which includes the distance of each pair of objects. The matrix is symmetrical about the main diagonal, which is all zeros. Next, pairs of objects are searched (and in the further part of clusters) for which the mutual distance is the smallest. It should be assumed that the objects are marked as " $p$ " and " $q$ ", where $p<q$. Successively, " $p$ " and " $q$ " are merged into one new cluster that occupies the position number " $p$ ". At the same time, the object (cluster) with the number " $q$ " is removed, and the numbers of the clusters with a higher number are reduced by one. Thus, the dimension of the matrix decreases by 1 . Next, the distance of the new cluster from each remaining cluster is determined according to the formula:

$$
D_{p r}=a_{1} \cdot d_{p r}+a_{2} \cdot d_{q r}+b \cdot d_{p q}
$$

$D_{p r}$ - the distance of the new cluster from the cluster number " $r$ "

$d_{p r}$ - the distance of the primary cluster " $p$ " from the cluster " $r$ "

$d_{q r}$ - the distance of the primary cluster " $q$ " from cluster " $r$ "

$d_{p q}$ - mutual distance of primary clusters " $p$ " and " $q$ "

$a_{1}, a_{2}, b$-parameters calculated in the Ward's method on the basis of the following formulas:

$$
a_{1}=\frac{n_{p}+n_{r}}{n_{p}+n_{q}+n_{r}} \quad a_{2}=\frac{n_{q}+n_{r}}{n_{p}+n_{q}+n_{r}} \quad b=\frac{-n_{r}}{n_{p}+n_{q}+n_{r}}
$$

in the formulas " $n$ " means the number of individual objects in particular groups.

The group means method was used to describe the formed clusters. For the clusters obtained, the analysis of group means was carried out in order to show the indicators dominant in a given group. For the matrix of numerical data, the arithmetic means of the examined indicators were calculated, denoted by $\bar{W}_{i}$. Next, the arithmetic means of the indicators in the obtained clusters were calculated, which were marked as $\overline{\mathrm{w}}_{\mathrm{i}}$. The index of the structure of each cluster is the quotient $\frac{\overline{\mathrm{W}}_{i}}{\overline{\mathrm{W}}_{\mathrm{i}}}$. The maximum value of the structure index provides information about the dominance of a given feature in the obtained group. The average level of the phenomenon is 1 . The values above 1 are indicators greater than the average, and the values below 1 are indicators for which the level in individual groups is lower than average.

\section{Research Results}

The first stage of the analysis was the assessment of the basic financial ratios. The enterprises were divided into two groups: large and small enterprises. The detailed results are presented in Table 1. 
Table 1. Descriptive statistics of the basic financial ratios.

\begin{tabular}{|c|c|c|c|c|c|c|c|}
\hline \multirow{2}{*}{ Indicator } & \multirow{2}{*}{ Descriptive Statistics } & \multicolumn{3}{|c|}{ Large } & \multicolumn{3}{|c|}{ Small } \\
\hline & & 2017 & 2018 & 2019 & 2017 & 2018 & 2019 \\
\hline \multirow{4}{*}{ Liquidity } & $\bar{x}$ & 1.47 & 1.36 & 1.57 & 2.95 & 2.43 & 3.43 \\
\hline & $\sigma$ & 0.40 & 0.29 & 0.20 & 2.07 & 0.72 & 0.16 \\
\hline & Min & 0.89 & 0.92 & 1.23 & 1.48 & 1.92 & 3.32 \\
\hline & Max & 1.94 & 1.81 & 1.79 & 4.41 & 2.93 & 3.55 \\
\hline \multirow{4}{*}{$\begin{array}{c}\text { Share of inventories in current } \\
\text { assets }\end{array}$} & $\bar{x}$ & 0.28 & 0.26 & 0.23 & 0.29 & 0.27 & 0.21 \\
\hline & $\sigma$ & 0.16 & 0.14 & 0.14 & 0.17 & 0.27 & 0.20 \\
\hline & Min & 0.12 & 0.06 & 0.03 & 0.18 & 0.08 & 0.06 \\
\hline & Max & 0.53 & 0.50 & 0.44 & 0.41 & 0.46 & 0.35 \\
\hline \multirow{4}{*}{$\begin{array}{l}\text { Short term receivables turnover in } \\
\text { days }\end{array}$} & $\bar{x}$ & 84.32 & 74.57 & 68.36 & 41.52 & 24.07 & 56.89 \\
\hline & $\sigma$ & 40.75 & 34.23 & 32.10 & 32.12 & 7.20 & 19.83 \\
\hline & Min & 44.11 & 34.34 & 36.76 & 18.81 & 18.98 & 42.87 \\
\hline & Max & 165.67 & 138.54 & 132.77 & 64.23 & 29.16 & 70.91 \\
\hline \multirow{4}{*}{$\begin{array}{l}\text { Short-term liabilities rotation short } \\
\text { in days }\end{array}$} & $\bar{x}$ & 127.29 & 129.62 & 98.12 & 75.78 & 53.21 & 44.50 \\
\hline & $\sigma$ & 71.30 & 67.02 & 33.32 & 13.78 & 18.52 & 26.91 \\
\hline & Min & 80.43 & 71.00 & 66.91 & 66.04 & 40.11 & 25.47 \\
\hline & Max & 293.69 & 280.71 & 145.71 & 85.52 & 66.31 & 63.54 \\
\hline \multirow{4}{*}{$\begin{array}{c}\text { Share of receivables in current } \\
\text { assets }\end{array}$} & $\bar{x}$ & 0.51 & 0.46 & 0.51 & 0.18 & 0.24 & 0.41 \\
\hline & $\sigma$ & 0.19 & 0.23 & 0.21 & 0.05 & 0.20 & 0.14 \\
\hline & Min & 0.29 & 0.14 & 0.11 & 0.15 & 0.10 & 0.31 \\
\hline & Max & 0.75 & 0.75 & 0.72 & 0.22 & 0.38 & 0.51 \\
\hline \multirow{4}{*}{ Quick } & $\bar{x}$ & 1.04 & 1.01 & 1.21 & 1.91 & 1.67 & 2.71 \\
\hline & $\sigma$ & 0.32 & 0.34 & 0.29 & 0.97 & 0.14 & 0.58 \\
\hline & Min & 0.62 & 0.68 & 0.95 & 1.22 & 1.57 & 2.30 \\
\hline & Max & 1.57 & 1.54 & 1.73 & 2.59 & 1.77 & 3.12 \\
\hline \multirow{4}{*}{ ROS profitability } & $\bar{x}$ & 0.04 & 0.03 & 0.03 & -0.04 & 0.01 & 0.02 \\
\hline & $\sigma$ & 0.03 & 0.03 & 0.02 & 0.06 & 0.01 & 0.02 \\
\hline & Min & 0.01 & 0.00 & 0.01 & -0.08 & 0.00 & 0.01 \\
\hline & Max & 0.11 & 0.11 & 0.08 & 0.00 & 0.02 & 0.04 \\
\hline \multirow{4}{*}{ Share of fixed assets in assets } & $\bar{x}$ & 0.26 & 0.27 & 0.27 & 0.45 & 0.39 & 0.40 \\
\hline & $\sigma$ & 0.21 & 0.20 & 0.17 & 0.39 & 0.39 & 0.38 \\
\hline & Min & 0.11 & 0.10 & 0.11 & 0.18 & 0.11 & 0.13 \\
\hline & $\operatorname{Max}$ & 0.73 & 0.72 & 0.63 & 0.73 & 0.66 & 0.67 \\
\hline
\end{tabular}

Source: own study based on the financial statements of the analyzed enterprises.

When analyzing the results from Table 1, differences in several important indicators are clearly visible. In the case of small enterprises, high results for the financial liquidity ratio can be seen. Therefore, it can be concluded that this represents excess liquidity. This is also confirmed by the high results of the speed ratio. When analyzing the turnover ratios of short-term receivables in days and short-term liabilities in days, differences are also visible. Small enterprises cannot afford long crediting of recipients; therefore, the receivables turnover ratios in days are much lower compared to large enterprises. The same can be seen in the case of the liability turnover in days. The quick process of collecting receivables from customers in small enterprises leads to a low share of short-term receivables compared to large enterprises. The share of inventories in current assets in enterprises is at a similar level. These results indicate a high share of cash in hand and at the bank in the case of groups of small enterprises, which has a positive impact on the financial security of small businesses. Excess liquidity means low profitability, which is confirmed by the results of sales profitability indicators. Here, large enterprises achieve higher results. High liquidity and low profitability confirm the rule that it is difficult to obtain high profits with excess liquidity, which is confirmed by many studies conducted worldwide. 
Next, using the non-parametric Mann-Whitney U test, we checked whether there were differences in the level of the indicators in the periods analyzed, broken down into large and small companies. The test results are presented in Table 2.

Table 2. Mann-Whitney U test results. Company size and differences in the level of selected indicators.

\begin{tabular}{cccc}
\hline & $\mathbf{2 0 1 7}$ & $\mathbf{2 0 1 8}$ & $\mathbf{2 0 1 9}$ \\
\hline Liquidity & & $\boldsymbol{p}$-Value & 0.0444 \\
Share of inventories in current assets & 0.4000 & 0.0444 & 1.0000 \\
Short term receivables turnover in days & 0.2667 & 1.0000 & 0.7111 \\
Short-term liabilities rotation short in days & 0.1778 & 0.0444 & 0.0444 \\
Share of receivables in current assets & 0.0444 & 0.0444 & 0.4000 \\
Quick & 0.1778 & 0.4000 & 0.0444 \\
ROS profitability & 0.0444 & 0.2667 & 0.5333 \\
Share of fixed assets in assets & 0.7111 & 1.0000 & 0.8888 \\
\hline
\end{tabular}

Source: own study based on the financial statements of the analyzed enterprises.

The research shows that the share of inventories in current assets and the share of fixed assets in assets is at a similar level in large and small companies in all the analyzed periods (2017-2019). Significant differences were noted in the case of other indicators.

Figures 1-6 show the difference based on the Mann-Whitney U results.

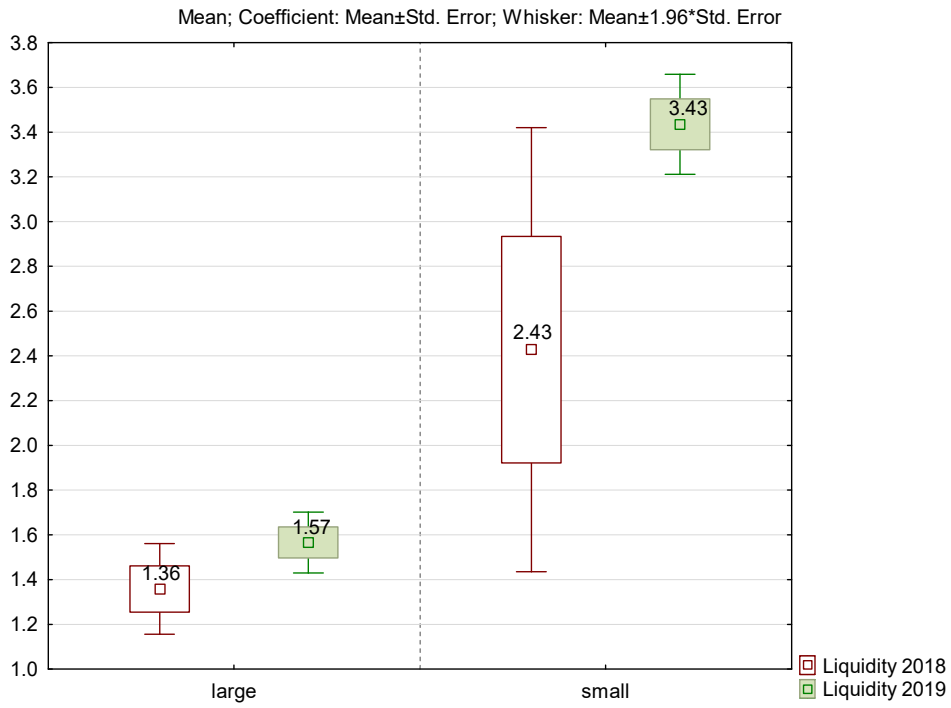

Figure 1. Liquidity in 2018 and 2019 in relation to the size of the company. 


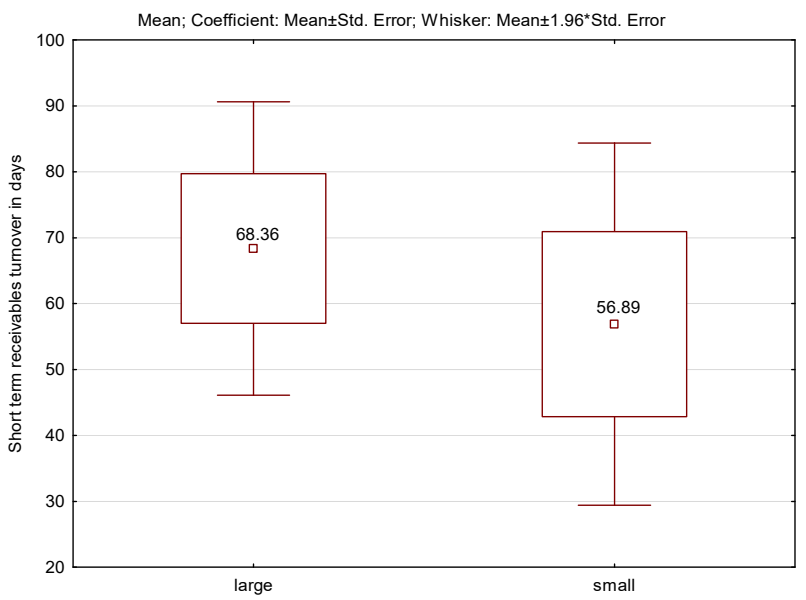

Figure 2. Rotation of short-term receivables in days in relation to the company's size.

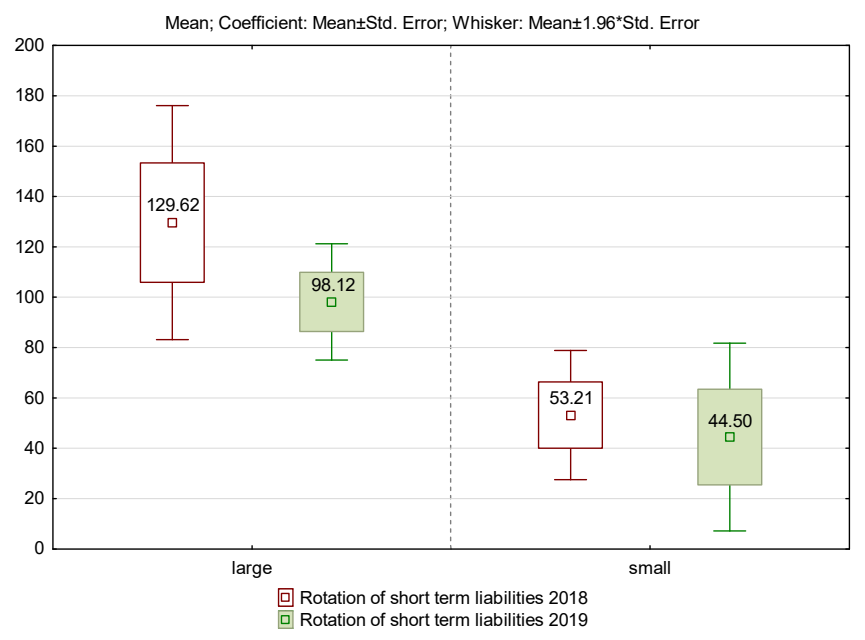

Figure 3. Rotation of short-term liabilities in 2018 and 2019, broken down by company size.

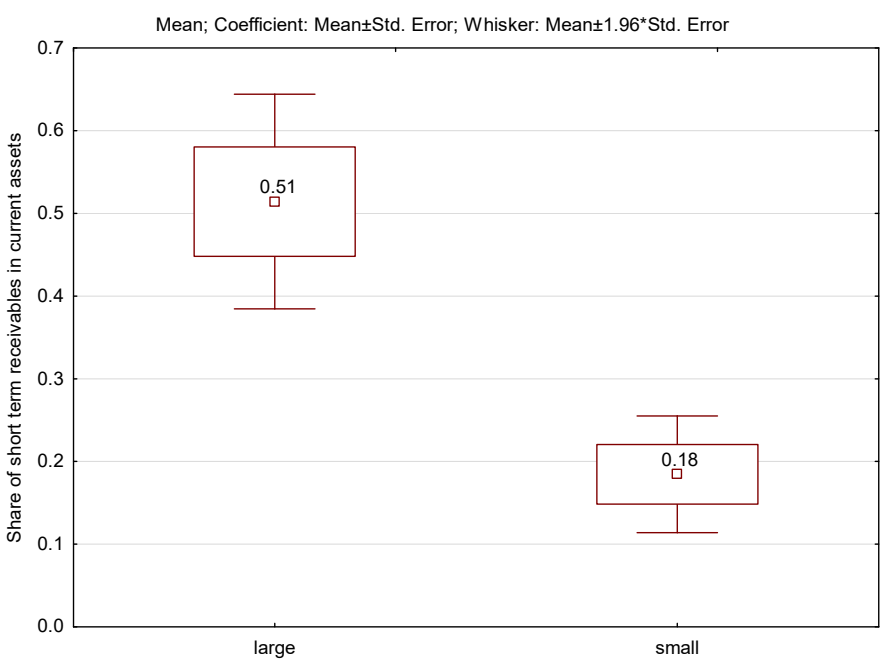

Figure 4. Share of short-term receivables in current assets in 2017 in relation to the company's size. 


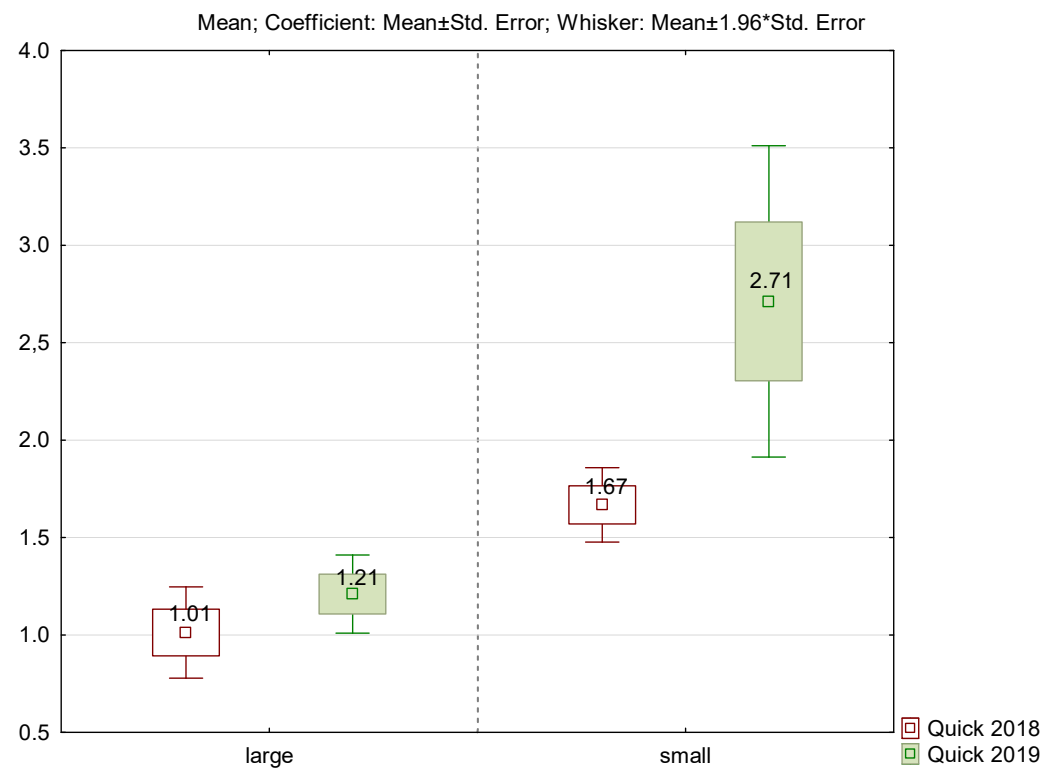

Figure 5. Speed indicator by company size in 2018 and 2019.

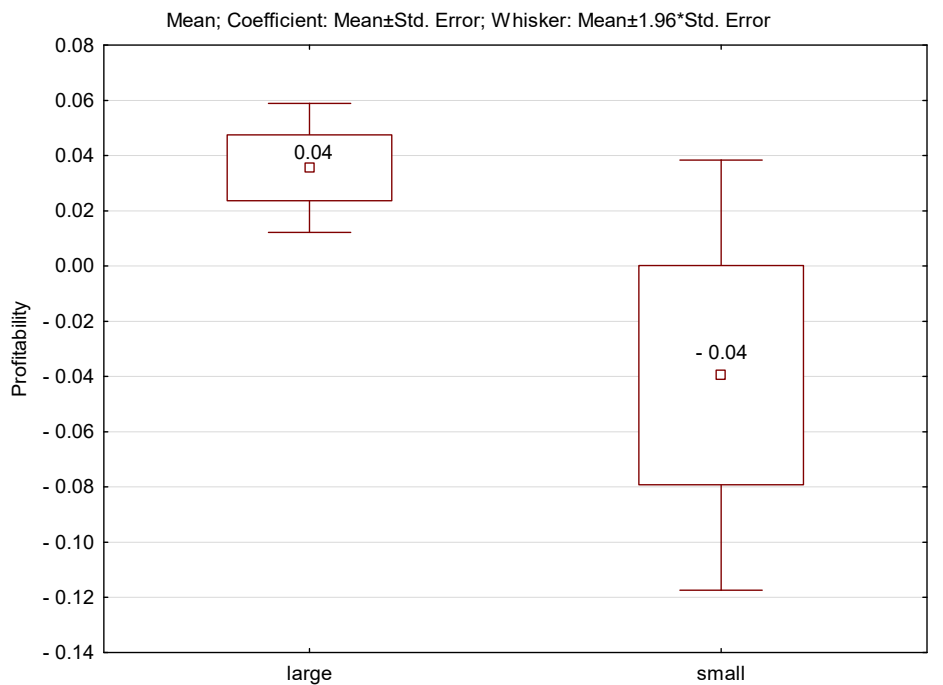

Figure 6. Profitability by company in 2017.

The liquidity ratio was differentiated both in 2018 and 2019. Significantly higher values for the liquidity ratio were recorded in small companies. The rotation of short-term receivables in days showed a difference between small and large only in 2018. Large companies displayed higher index values. The details are presented in Figures 1 and 2.

The rotation of short-term liabilities in days shows differentiation both in 2018 and 2019. Much higher indicator values occurred in large companies, although the difference decreased in 2019.

The share of receivables in current assets differed only in 2017. Larger index values were displayed by large companies. In the remaining years, the differences were not statistically significant. The details are presented in Figures 3 and 4.

The size of the speed indicator also varied in relation to the size of the company, both in 2018 and 2019. The indicator was higher in small companies, and in 2019 the difference even deepened. The last indicator adopted for the research showing differences between small and large companies is ROS profitability. Profitability differences occurred only in 2017. Large companies displayed much higher values for the indicator. The details are presented in Figures 5 and 6. 
Subsequently, on the basis of the indicators adopted for the study, a taxonomic analysis was carried out, which made possible the determination of the structure of the resulting groups in terms of the financial indicators adopted for the study. The clustering was performed in three analyzed periods and, on the basis of cluster trees, it was determined which clusters were formed from the analyzed construction companies. The resulting groups were homogeneous, i.e., the companies that made up each cluster were similar to each other in terms of the analyzed indicators, while the groups differed from each other. The grouping results for particular years are shown in Figures 7-9.

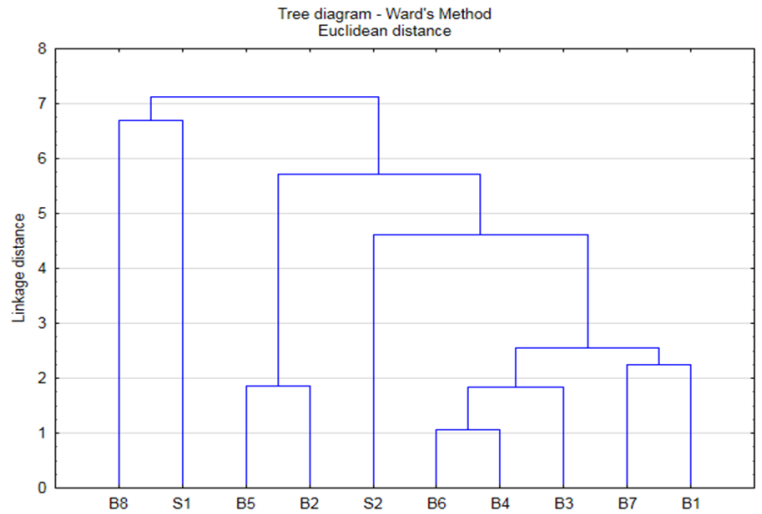

Figure 7. Grouping results in 2017.

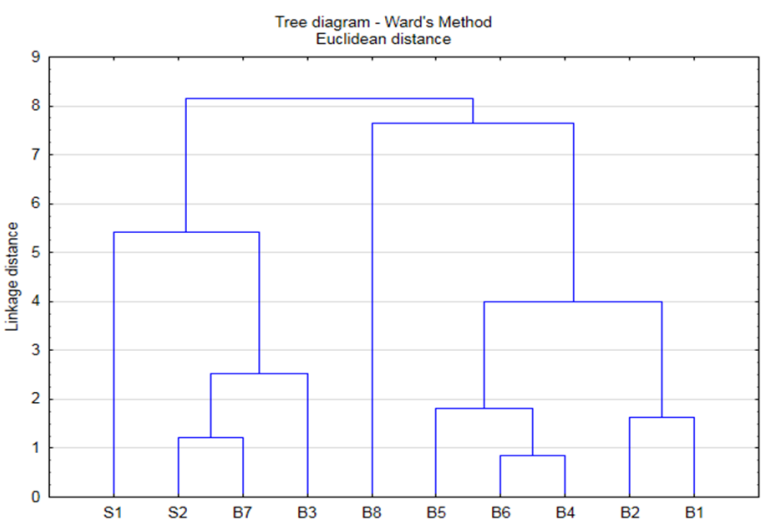

Figure 8. Grouping results in 2018.

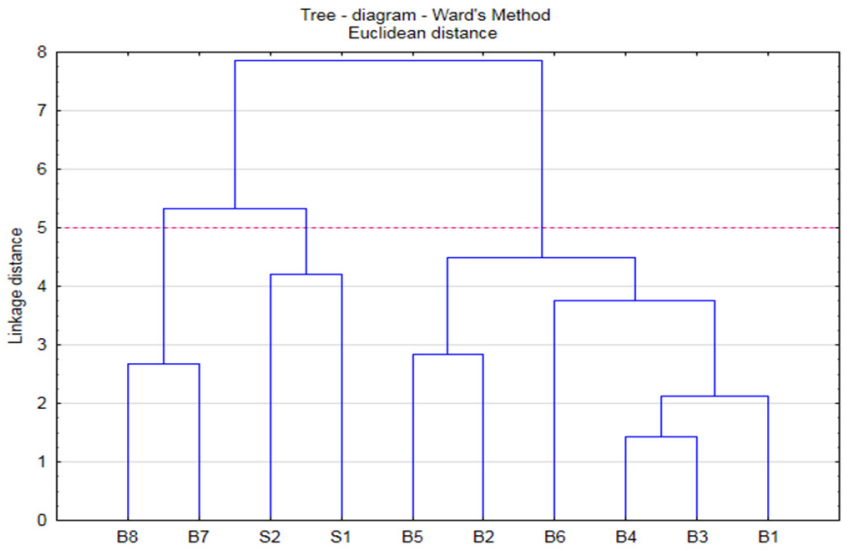

Figure 9. Grouping results in 2019.

On the basis of the dendrogram, we analyzed how individual clusters changed in the years studied (Table 3). In 2017 and 2018, the companies were divided into four groups. 
Single-element clusters were created by the companies B8 and S1. The most numerous groups included: six companies in 2017, five companies in 2018 and six companies in 2019. In 2017 and 2018, companies created four clusters, and in 2019 there were only three clusters, which may mean greater similarities in terms of the analyzed indicators in the analyzed companies.

Table 3. Cluster structure in 2017-2019.

\begin{tabular}{cccc}
\hline Clusters & $\mathbf{2 0 1 7}$ & $\mathbf{2 0 1 8}$ & $\mathbf{2 0 1 9}$ \\
\hline Group 1 & B8 & B8 & B8, B7 \\
Group 2 & S1 & S1 & S1, S2 \\
Group 3 & B2, B5 & S2, B7, B3 & B1, B2, B3, B4, B5, B6 \\
Group 4 & S2, B6, B4, B3, B7, B1 & B1, B2, B4, B6, B5 & \\
\hline Source: own study based on the financial statements of the analyzed enterprises.
\end{tabular}

When analyzing the changes that took place in the clusters, two small companies, S1 and S2, eventually formed one group, although in the previous years they were not similar in terms of the analyzed indicators. Another two-element cluster that was created in 2019 was that of the B7 and B8 companies. On the other hand, the third group included other enterprises. Why the clustering for the last period was carried out in this way is explained by the graph, which was constructed on the basis of group means. The details are presented in Table 3.

The chart of group averages shows that group 1 (B7 and B8) was characterized by low liquidity ratios, share of inventories in current assets, low rotation of short-term receivables in days and a low ratio of receivables in current assets. On the other hand, the highest values were displayed by the following ratios: the share of fixed assets in assets and profitability. Above the average level was the short-term liability turnover ratio in days. These enterprises use trade credits to a large extent; low liquidity allows them to obtain high profitability. High levels of profitability are certainly influenced by the low share of inventories in the structure of current assets. Compared to other groups in this group of enterprises, a low ratio of receivables turnover in days was observed, which should be assessed positively from the point of view of financial liquidity. Group A companies base their activities on their fixed assets. This group was made up of market leaders, the largest enterprises (Figure 10).

The second group included two small companies, S1 and S2. These companies demonstrated very high liquidity and speed ratios, as well as a high ratio of fixed assets to assets. This is confirmed by the high results of the share of inventories in current assets. The high share of inventories in the structure of current assets and excess liquidity were reflected in the low results of the financial profitability ratios. The remaining indicators were below the global average (Figure 10).

Six companies were gathered in the last, third, group: B1, B2, B3, B4, B5, B6. These were large construction companies that were characterized by the highest ratios of the share of inventories in current assets, the rotation of short-term receivables in days, and the share of receivables in current assets. Their short-term liability turnover ratio in days was also high. The remaining indicators featured values below the global average. The lowest values in this group were: the liquidity ratio, speed, and the share of fixed assets in assets (Figure 10). 


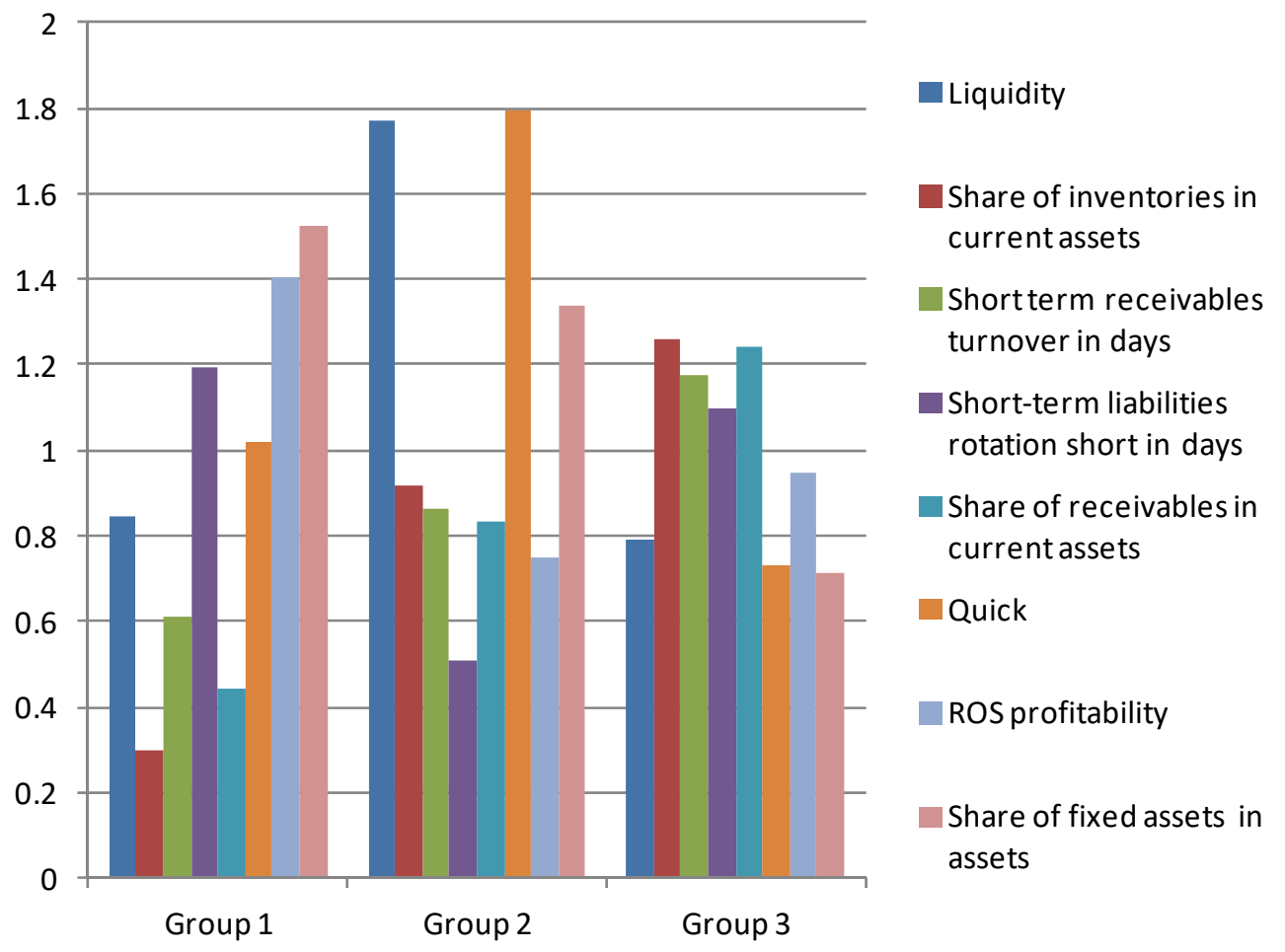

Figure 10. Group means for individual clusters. Source: own study based on the financial statements of the analyzed enterprises.

\section{Discussion and Conclusions}

All over the world, research studies confirm that high liquidity means low profitability and vice versa (Enqvist et al. 2014; Zimon and Zimon 2020; Salehi et al. 2019). Kim et al. (1998) reveal that there is a negative relationship between liquidity, debt ratio and the probability of financial distress. Baveld (2012) found negative relationships between gross profit and financial liquidity in Netherlands companies.

In turn, in the medical industry, there are studies that indicate the positive impact of financial liquidity on profitability (Batrancea 2021). This relationship was also observed in the studies conducted. An interesting fact is that they were small enterprises that recorded excess liquidity and low profitability. In turn, the largest enterprises recorded very good results in terms of profitability and low financial liquidity, but within a safe range corresponding to the standards. It can be seen that the economies of scale and high turnover allow the largest enterprises to obtain very good results. The results of this research make it possible to positively verify the theses.

Therefore, in current research, one can find a number of studies whose authors claim that cooperation in multi-entity organizations makes it possible to obtain a scale effect and very good financial results (Faes et al. 2000; Tella and Virolainen 2005; Burns and Lee 2008; Schotanus and Telgen 2007; Sandberg and Mena 2015; Zimon and Zimon 2020).

When analyzing the individual results, it should be stated that small enterprises use a safe (conservative) liquidity management strategy. It is difficult to obtain attractive trade credits in such units; therefore, the liability turnover in days is low. In small enterprises, there are also problems with collecting receivables from recipients; therefore, the receivables turnover ratios in days are at a higher level compared to the liability turnover in days.

On the other hand, large enterprises try to use moderate strategies. This is confirmed by the low results of financial liquidity ratios and high profitability. The liquidity ratios are within the benchmark ranges. The remaining indicators show average results.

In turn, in the case of market leaders, it is difficult to define liquidity management strategies. These can be described as moderately aggressive. Financial liquidity ratios are higher than the results in large enterprises. Profitability is definitely the highest, as is the 
share of fixed assets in total assets. In the case of fixed assets, machinery, equipment and means of transport account for a large share in enterprises. Perhaps investing in one's own fixed assets allows increasing profitability. However, it is difficult to judge this on the basis of small studies conducted in this area. Low share of inventories, receivables and extended credit terms by suppliers allow increasing profitability. An aggressive approach to debt collection makes it possible to obtain cash and invest it in fixed assets.

Based on the analyses, it is clear that in the case of market leaders, the scale of sales allows high profitability, but this type of strategy should be based on a long loan period, optimal management of receivables and snowdrifts. Such a policy of managing current assets makes it possible to obtain an average level of financial liquidity. In summary, it can be stated that in the case of industries that are dynamically developing in the Podkarpackie Province, better results in the area of financial liquidity and profitability are achieved by enterprises that generate high turnover. In such units, thanks to the scale effect and high sales volumes, the introduction of even a low dream makes it possible to cover fixed costs. The margin on sales may be low, but the sales volume allows one to cover the indirect costs of production, which enables profits. If, in addition, the enterprise effectively manages individual elements of current assets and current liabilities, the enterprises also obtain a safe level of financial liquidity.

The results presented for the largest enterprises demonstrate their sustainable development and the likelihood that they will maintain their position as market leaders.

However, the limitations of this study result from the fact that only ten entities from the construction industry were included in the study. However, they constitute the basis for further analyses, taking into account larger research samples.

Author Contributions: Conceptualization, G.Z., J.N., K.C.-L., M.W.-J. and K.K.; methodology, K.C.-L.; formal analysis, G.Z.; investigation, G.Z., J.N., K.C.-L., M.W.-J. and K.K.; resources, G.Z. and J.N.; data curation, G.Z.; writing—original draft preparation, G.Z., J.N., K.C.-L., M.W.-J. and K.K.; writingreview and editing, G.Z., J.N., K.C.-L., M.W.-J. and K.K.; visualization, G.Z., J.N., K.C.-L., M.W.-J. and K.K.; supervision, G.Z., J.N., K.C.-L., M.W.-J. and K.K. All authors have read and agreed to the published version of the manuscript.

Funding: This publication was co-financed by a subsidy granted to the Cracow University of Economics.

Data Availability Statement: National Court Register. The financial statements are available from the court where the companies file them.

Conflicts of Interest: The authors declare no conflict of interest.

\section{References}

Akgün, Ali Ishan, and Memis Karatas Ayyüce. 2021. Investigating the relationship between working capital management and business performance: Evidence from the 2008 financial crisis of EU-28. International Journal of Managerial Finance 17: 545-67. [CrossRef]

Andrew, Agbada, and C. C. Osuji. 2013. The efficacy of liquidity management and banking performance in Nigeria. International Review of Management and Business Research 2: 223-33.

Batrancea, Larissa. 2021. The Influence of Liquidity and Solvency on Performance within the Healthcare Industry: Evidence from Publicly Listed Companies. Mathematics 9: 2231. [CrossRef]

Baveld, Mathias B. 2012. Impact of Working Capital Management on the Profitability of Public Listed Firms in the Netherlands during the Financial Crisis. Master's thesis, School of Management and Governance, University of Twente, Enschede, The Netherlands. Available online: http:/ / essay.utwente.nl/61524/1/MSc_M_Baveld.pdf (accessed on 1 May 2012).

Bei, Zhao, and Witchange Percy Wijewardana. 2012. Working capital policy practice: Evidence from srilankan companies. Procedia-Social and Behavioral Sciences 40: 695-700. [CrossRef]

BGK. 2019. Raport z badania sektora budowlanego 2019. Available online: https://www.bgk.pl/files/public/Pliki/dla_mediow / Raport_z_badania_sektora_budowlanego.pdf (accessed on 1 March 2020).

BIG. 2019. Sytuacja finansowa Przedsiębiorstw Budowlanych. Niestabilna kondycja branży na szczycie koniunktury. Ogólnopolski Raport Biura Informacji Gospodarczej InfoMonitor o zadłużeniu firm z sektora budowlanego. Available online: http:/ / pzpb. com.pl/wp-content/uploads/2019/04/Raport-Boom-trwa-ryzyko-nie-maleje-III-edycja.pdf (accessed on 7 July 2021).

Burns, Lawton R. 2002. Role of group purchasing organizations (GPOs). In The Health Care Value Chain. Edited by Lawton R. Burns. San Francisco: John Wiley \& Sons, pp. 59-125. 
Burns, Lawton R., and J. Andrew Lee. 2008. Hospital purchasing alliances: Utilization, services, and performance. Health Care Management Review 33: 203-15. [CrossRef]

Cattell, Richard. 1944. Note on correlation clusters and cluster search methods. Psychonometrica 9: 169-84. [CrossRef]

Chen, You-Shyang, Chien-Ku Lin, Chin-Min Lo, Su-Fen Chen, and Qi-Jun Liao. 2021. Comparable Studies of Financial Bankruptcy Prediction Using Advanced Hybrid Intelligent Classification Models to Provide Early Warning in the Electronics Industry. Mathematics 9: 2622. [CrossRef]

Chiou, J.-R., L. Cheng, and H.-W. Wu. 2006. The determinants of net working capital management. Journal of American Academy for Business 10: 149-155.

Chłodnicka, Halina, and Grzegorz Zimon. 2020. Bankruptcu Risk Assessment Measures of Polish SMEs. WSEAS Transactions on Business and Economics 17: 14-20. [CrossRef]

Chowdhury, Md. Mohiuddin, and Safir Zaman. 2018. Effect of liquidity risk on performance of Islamic banks in Bangladesh. IOSR Journal of Economics and Finance (IOSR-JEF) 9: 1-9.

Clampit, Jack, Dinesh Hasija, Michael Dugan, and John Gamble. 2021. The Effect of Risk, R\&D Intensity, Liquidity, and Inventory on Firm Performance during COVID-19: Evidence from US Manufacturing Industry. Journal of Risk and Financial Management 14: 499. [CrossRef]

Cowan, Anne E., Sarah J. Clark, Jennifer L. Gordon, Karin Bok, and Angela K. Shen. 2016. Vaccine purchasing groups in the United States: An overview of their policies and practices. Vaccine 34: 5060-65. [CrossRef]

Deloof, Marc. 2003. Does working capital management affect profitability of Belgian firms? Journal of Business Finance and Accounting 30: 573-87. [CrossRef]

Ding, Sai, Guariglia Alessandra, and John Knight. 2013. Investment and financing constraints in China:does working capital management make a difference? Journal of Banking $\mathcal{E}$ Finance 37: 1490-507.

Doucette, William R. 1997. Influences on member commitment to group purchasing organizations. Journal of Business Research 40: 183-89. [CrossRef]

Eldomiaty, Tarek, Marwa Anwar, and Ahmed Ayman. 2018. How can firms monitor the move toward optimal working capital? Journal of Economic and Administrative Sciences 34: 217-23. [CrossRef]

Enqvist, Julius, Michael Graham, and Jussi Nikkinen. 2014. The impact of working capital management on firm profitability in different business cycles: Evidence from Finland. Research in International Business and Finance 32: 36-49. [CrossRef]

Faes, Wouter, Paul Matthyssens, and Koen Vandenbempt. 2000. The pursuit of global purchasing synergy. Industrial Marketing Management 29: 539-53. [CrossRef]

Gajdka, Joanna, and Ewa Walińska. 2000. Zarzązanie finansowe spółek kapitałowych. Warszawa: FRR w Polsce, p. 465.

Garcia-Appendini, Emilia, and Judith Montoriol-Garriga. 2013. Firms as liquidity providers: Evidence from the 2007-2008 financial crisis. Journal of Financial Economics 109: 272-91. [CrossRef]

Garcia-Teruel, Pedro, and Pedro Martınez-Solano. 2007. Short-term Debt in Spanish SMEs. International Small Business Journal 25: 579-602. [CrossRef]

Goldmann, Katarzyna. 2014. Trendy zarządzania płynnością finansową-Wyniki badań. Prace Naukowe Uniwersytetu Ekonomicznego we Wroclawiu 344: 194-202. [CrossRef]

Grabiński, Tadeusz. 1992. Metody taksonometrii. Kraków: Wydawnictwo Akademii Ekonomicznej w Krakowie.

Hendrick, Thomas E. 1997. Purchasing Consortiums: Horizontal Alliances among Firms Buying Common Goods and Services: What? Who? Why? How? Tempe: Center for Advanced Purchasing Studies (CAPS) Research.

Higgins, Robert C. 2009. Analysis for Financial Management. New York: McGraw-Hill.

Kim, Chang Soo, David C. Mauer, and Anna Sherman. 1998. The determinants of corporate liquidity: Theory and evidence. Journal of Financial and Quantitative Analysis 33: 305-34. [CrossRef]

Kusak, Aleksander. 2006. Płynność finansowa Analiza i sterowanie. Warszawa: Wydawnictwo naukowe Wydziału Zarządzania Uniwersytetu Warszawskiego.

Mamatzakis, Emmanuel, and Theodora Bermpei. 2014. What drives bank performance? The role of Risk, Liquidity and fees prior to and during the performance. International Review of Financial Analysis 35: 102-17. [CrossRef]

Mosiejko, Leszek, Bernardelli Michał, and Sierant Artur. 2019. Płynność finansowa spółek notowanych na Giełdzie Papierów Wartościowych w Warszawie SA w latach 2002-2017 w ujęciu sektorowym—część 1. Studia i Prace Kolegium Zarzadzania i Finansów 173: 9-27.

Mun, Sung Gyuan, and Soocheong Jang. 2015. Working capital, cash holding, and profitability of restaurant firms. International Journal of Hospitality Management 48: 1-11. [CrossRef]

Nollet, Jean, and Martin Beaulieu. 2005. Should an organisation join a purchasing group? Supply Chain Management: An International Journal 10: 11-17. [CrossRef]

Nollet, Jean, Martin Beaulieu, and Nathalie Fabbe-Costes. 2017. The impact of performance measurement on purchasing group dynamics: The Canadian experience. Journal of Purchasing and Supply Management 23: 17-27. [CrossRef]

Peel, Michael, Nicholas Wilson, and Carole Howorth. 2000. Late payment and credit management in the small firm sector: Some empirical evidence. International Small Business Journal 18: 17-37. [CrossRef] 
Popescu, Cristina Raluca, and Gheorghe Popescu. 2019. An Exploratory Study Based on a Questionnaire Concerning Green and Sustainable Finance, Corporate Social Responsibility, and Performance: Evidence from the Romanian Business Environment. Journal of Risk and Financial Management 12: 162. [CrossRef]

Puławska, Karolina. 2021. Financial Stability of European Insurance Companies during the COVID-19 Pandemic. Journal of Risk and Financial Management 14: 266. [CrossRef]

Salehi, Mahdi, Nadia Mahdavi, Saeed Zarif Agahi Dari, and Hossein Tarighi. 2019. Association between the availability of financial resources and working capital management with stock surplus returns in Iran. International Journal of Emerging Markets 14: 343-61. [CrossRef]

Samiloglu, Famil, and Kartal Dermigunes. 2008. The effect of working capital management on firm profitability: Evidence from Turkey. The International Journal of Applied Economics and Finance 2: 44-50. [CrossRef]

Sandberg, Erik, and Carlos Mena. 2015. Exploring strategic strengths and weakness of retail purchasing groups. The International Review of Retail, Distribution and Consumer Research 25: 276-97. [CrossRef]

Schneller, Eugene S. 2000. The Value of Group Purchasing in the Health Care Supply Chain. Tempe: School of Health Administration and Policy.

Schotanus, Fredo, and Jan Telgen. 2007. Developing a typology of organizational forms of cooperative purchasing. Journal of Purchasing and Supply Management 13: 53-68. [CrossRef]

Sharma, Amit K., and Satish Kumar. 2011. Effect of working capital management on firm profitability: Empirical evidence from India. Global Business Review 12: 159-73. [CrossRef]

Sierpińska, Maria, and Tomasz Jachna. 1999. Ocena przedsiębiorstwa według standardów światowych. Warszawa: PWN, p. 79.

Tella, Eija, and Veli Matti Virolainen. 2005. Motives behind purchasing consortia. International Journal of Production Economics 93-94: 161-68. [CrossRef]

Tryon, Richard. 1939. Cluster Analysis. New York: McGraw-Hill.

Vahid, Taghizadeh Khanqah, Ghanavati Elham, Akbari khosroshahi Mohsen, and Ebrati Mohammadreza. 2012. Working capital management and corporate performance: Evidence from iranian companies. Procedia-Social and Behavioral Sciences 62: 1313-18. [CrossRef]

Waśniewski, Tomasz, and Wanda Skoczylas. 2004. Teoria i praktyka nalizy finansowej w przedsiębiorstwie. Warszawa: Fundacja rozwoju rachunkowości w Polsce.

Wawryszcuk-Misztal, Anna. 2007. Strategie zarzadzania kapitałem obrotowym netto w przedsiębiorstwach. Studium empiryczno-teoretyczne. Lublin: Wydawnictwo UMCS.

Wędzki, Dariusz. 2003. Strategie płynności finansowej przedsiębiorstwa. Przepływy pieniężne a wartość dla właścicieli. Kraków: Oficyna Wydawnicza.

Wskaźniki-wskaznikibranzowe.pl. 2021. Available online: https://wskaznikibranzowe.pl/2021 (accessed on 27 August 2021).

Zimon, Grzegorz, and Dominik Zimon. 2020. The Impact of Purchasing Group on the Profitability of Companies Operating in the Renewable Energy Sector-The Case of Poland. Energies 13: 6588. [CrossRef]

Zimon, Grzegorz, and Hossein Tarigh. 2021. Effects of the COVID-19 Global Crisis on the Working Capital Management Policy: Evidence from Poland. Journal of Risk and Financial Management 14: 169. [CrossRef]

Zimon, Grzegorz. 2020. Financial Liquidity Management Strategies in Polish Energy Companies. International Journal of Energy Economics and Policy 10: 365-68. [CrossRef]

Zimon, Grzegorz, Vitalina Babenko, Beata Sadowska, Katarzyna Chudy-Laskowska, and Blanka Gosik. 2021. Inventory Management in SMEs Operating in Polish Group Purchasing Organizations during the COVID-19 Pandemic. Risks 9: 63. [CrossRef] 